\title{
Management and outcomes in digestive cancer surgery: design and initial results of a multicenter cohort study
}

\author{
M. Espallargues ${ }^{1,2}$, C. Almazán ${ }^{1,2}$, C. Tebé ${ }^{1,2}$, R. Pla ${ }^{3}$, J. M. V. Pons ${ }^{1,2}$, E. Sánchez ${ }^{1,2}$, M. Mias ${ }^{1,2}$, \\ S. Alomar ${ }^{1}$ and J. M. Borràs ${ }^{4}$, on behalf of the ONCOrisc* Study Group \\ ${ }^{I}$ Catalan Agency for Health Technology Assessment and Research (CAHTA). Barcelona ${ }^{2}$ CIBER Epidemiología y Salud \\ Pública (CIBERESP). Spain. ${ }^{3}$ Bellvitge University Hospital. Hospitalet de Llobregat, Barcelona. Spain. \\ ${ }^{4}$ Master Plan in Oncology. Catalan Institute of Oncology. Barcelona, Spain
}

\begin{abstract}
Background: most studies that analyze the influence of structure factors on clinical outcomes are retrospective, based on clinical-administrative databases, and mainly focusing on surgical volume.

Objective: to study variations in the process and outcomes of oncologic surgery for esophagus, stomach, pancreas, liver metastases and rectum cancers in Catalonia, as well as the factors associated with these variations.

Patients and method: a retrospective (2002) and prospective (2003-05) multicenter cohort study. Data forms were designed to collect patient, process, and care outcome characteristics before surgery, at hospital discharge, and at 3 and 6 months after discharge. Main outcome measures were hospital and followup mortality, complications, re-interventions, and relapse rates.

Results: 49 hospitals (80\%) participated in the retrospective phase, 44 of which (90\%) also participated in the prospective phase: 3,038 patients (98\%) were included. No differences were observed in the profile of operated patients according to hospital level of complexity, but clinical-pathological staging and other functional status variables could not be assessed because of over $20 \%$ of missing values. There was significant variability in the volume of interventions as well as in certain aspects of the healthcare process depending on type of cancer and center complexity. High rates of esophageal cancer mortality (18.2\% at discharge, $27.3 \%$ at 6 months) and of complications and re-interventions for all cancers assessed, especially rectal cancer (18.4\% re-interventions at 6 months), were identified.

Conclusions: the study of the variability identified will require adequate risk-adjustment and should take into account different structure factors. It is necessary that information included in medical records be improved.
\end{abstract}

\footnotetext{
*At the end of the article the members of the ONCOrisc study group (Assessment of the therapeutic procedure and its outcomes in digestive oncology) are listed.
}

Received: 05-02-09.

Accepted: 26-05-09.

Correspondence: Mireia Espallargues. Agency for Health Technology Assessment and Research. Carrer de Roc Boronat, 81-95, 2 $2^{\mathrm{a}} .08005$ Barcelona, Spain.e-mail: mespallargues@aatrm.catsalut.net
Key words: Digestive cancer. Surgery. Medical practice variations. Structure, process, and outcomes of care.

Espallargues M, Almazán C, Tebé C, Pla R, Pons JMV, Sánchez E, Mias M, Alomar S, Borràs JM on behalf of the ONCOrisc Study Group. Management and outcomes in digestive cancer surgery: design and initial results of a multicenter cohort study. Rev Esp Enferm Dig 2009; 101: 680-696.

\section{INTRODUCTION}

One of the aspects that is most debated in oncologic surgery and other fields (both surgical and medical procedures) is the relationship between the volume of patients having undergone surgery and clinical outcomes. It has been 30 years since the relationship between increased volume and improved outcomes was described (1). However, this relationship is not always observed, and the reasons why it occurs remain unknown. Several hypotheses, especially relating to surgeon-related technical factors (26 ), have been considered. However, if better outcomes are obtained in several different procedures or pathologies, healthcare organization and coordination factors should also be sought. This may be especially useful in the case of oncology, where it is necessary for professionals from different specialties to work together in tackling with diagnosis and treatment: surgery, oncology, as well as the site's central and general services.

Most studies that have analyzed the influence of these physician-/center-related factors, particularly volume, on the variability of the process and outcome of cancer surgery are retrospective (7) and based on clinical-administrative databases (8). This explains why the most frequently examined outcome is hospital mortali- 
ty, why there is no adjustment for significant clinical variables (such as severity and length of disease, comorbidities and their treatment, or functional status), and why very short-term follow-ups are performed. This fact could explain the differences observed in some prospective studies with primary data (which enable the inclusion of a greater number of variables and have follow-ups which extend beyond the hospital period), in which the relationship between volume and outcomes is less consistent $(8,9)$.

Studies do not usually take into account other center-related factors that may influence outcomes, such as structure-related characteristics and process-related factors, as was suggested by A. Donabedian's approach for the assessment of health care quality $(10,11)$ (Fig. 1).

A multicenter cohort study, based on the "structure, process and outcomes" paradigm described, and overcoming the previous limitation, was presented with the aim of studying variations in the process and outcomes of oncologic digestive surgery in Catalonia. This manuscript describes the methodology employed, and the main results obtained are described.

\section{MATERIAL AND METHODS}

An observational study with retrospective and prospective follow-up of a cohort of patients who had undergone oncologic surgery for esophageal, pancreatic, rectal cancers, and liver metastases. All general surgery services at both public $(n=51)$ and private $(n=10)$ hospitals in Catalonia performing this type of procedure were invited to participate. The retrospective phase included all patients operated in 2002 who had undergone one of the surgical procedures described in the Annex (in any of the 4 procedure variables of the Hospital Discharge Minimum Basic Data Set -HDMBD).

In the prospective phase, patients who had undergone cancer surgery with the previous procedures were consecutively included for a period of 6 months (between November 2003 and July 2005). In both phases, patients who underwent re-intervention or procedures in two stages (with the first intervention taking place prior to the study period) were excluded. It was estimated that the inclusion of 2,500 patients with an expected overall mortality of about $15 \%$ at 6 months after surgery (8) would enable to establish the potential prognostic or predictive

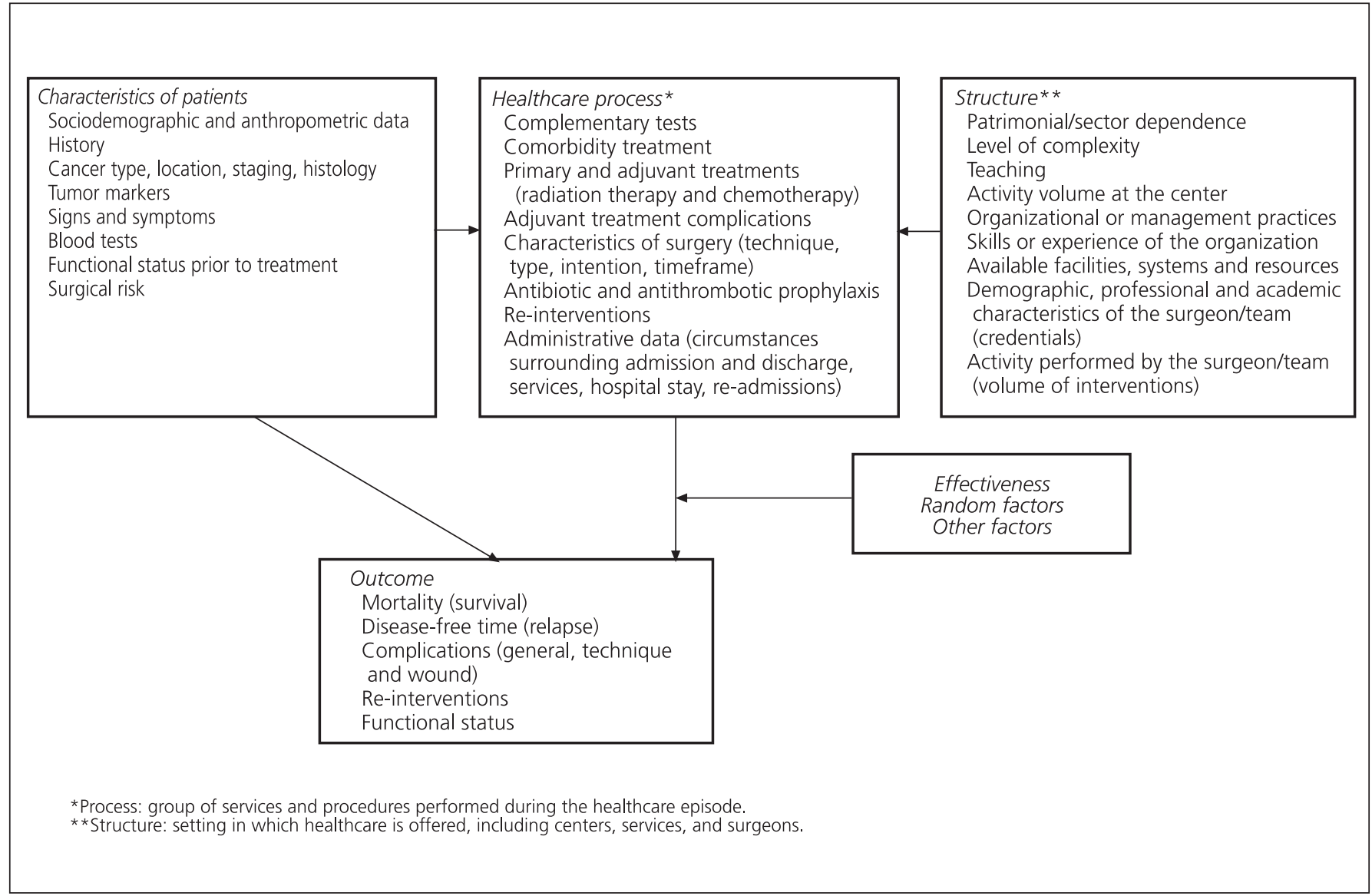

Fig. 1. Conceptual framework applied in the assessment of the digestive oncologic surgical process and its outcomes. Marco conceptual aplicado en la evaluación del proceso y los resultados en cirugía oncológica digestiva. 
role of approximately 30 independent variables in a stepby-step logistic regression analysis, hence creating a risk adjustment model (12) for mortality (primary outcome variable).

In the retrospective phase the main source of information was the medical record. In the prospective phase, data were obtained directly from the surgeon as much as possible, and also from the medical record. Assessments were performed in the pre-operative period, at discharge, and at 3 and 6 months. These assessments were carried out by healthcare professionals (mainly specialized surgeons or surgeons in training) specifically trained to this end.

Specific data collection forms were designed for each assessment period, and were accompanied by an instructional manual and operative definitions to standardize data collection. The pre-operative data collection form included data on administrative and demographic information, staging, diagnostic tests, complementary tests, blood tests, pathological medical history and treatment, neoadjuvant radiation therapy and chemotherapy (primary), functional status - using Karnofsky's Performance Score (13) and the Glasgow Coma (14-15) scales - and surgical-anesthetic risk - ASA scale - American Society of Anesthesiology (16). The data collection form at hospital discharge gathered data on surgical procedure (prophylaxis, tumor location, surgical technique - access route, resection, lymphadenectomy, reconstruction, anastomosis -, residual tumor, red blood cell and plasma bags, and length of surgery), intra- and postoperative complications (general, local, pertaining to the surgical technique, re-intervention and death), and administrative data. In the data collection forms at 3 and 6 months follow-up information was obtained on complications, relapses, re-admittances, pathology, adjuvant radiation therapy and chemotherapy (postoperative), and functional status (Karnofsky scale only at 6 months). Pilot tests were performed in each study phase to test data collection forms and to identify problems in communication circuits, data collection, and coordination tasks between centers and research team.

An internal validation of the quality and consistency of the information introduced into the database was performed using the Cardiff $^{\mathrm{TM}}$ TeleForm ${ }^{\circledR}$ system.

\section{Analysis}

An analysis of participation was carried out. The main demographic, clinical and process and outcome characteristics of the patients included were described and compared by type of cancer and by level of center complexity (regional, reference, high technology, and private). In order to study the association between risk, process, and outcome variables, a $\mathrm{Chi}^{2}$ test was applied for categorical variables and Student's t-test or Mann-Whitney's U (taking into account variable distribution) for continuous variables. A survival analysis was also conducted using the time elapsed from admission until 6 months on follow-up, loss to follow-up, or patient death. Results were stratified by type of cancer, and arbitrarily used a 5\% level of significance. Data management and statistical analyses were carried out using the SPSS v.13 and STATA v.9.

The identity of participants (patients, surgeons, and centers) was kept strictly confidential. The study protocol was assessed and approved by one of the Ethics Committees of Clinical Research of the participating centers.

\section{RESULTS}

\section{Participation}

Out of the 61 centers that in 2002 had performed a surgical procedure of interest to this study, $49(80 \%)$ agreed to participate (45 public centers and 4 private ones). Out of these, the vast majority (90\%) continued to participate in the prospective phase of the study. Overall, participating hospitals managed $94 \%$ of patients of interest throughout Catalonia, and the participation of private hospitals was significantly lesser than that of public hospitals (40 versus 88\%). Figure 2 shows the diagram for individual participation by phases.

\section{Patient characteristics}

The most frequent procedures were for rectal cancer $(55.6 \%)$, followed by stomach $(26.6 \%)$, liver metastases $(7.5 \%)$, pancreatic $(7.0 \%)$, and esophageal $(3.3 \%)$ cancer. The volume of procedures in each center by type of cancer and level of complexity (Fig. 3) showed high variability. Centralization for esophageal, pancreatic, and liver metastases was observed, as procedures for these types of cancer were performed almost exclusively in reference and high-technology hospitals. Larger volume was also associated with higher center complexity, mainly for stomach and rectum cancers.

Table I shows the main demographic and clinical characteristics of patients included in this study. Even though no differences were observed in the profile of patients by level of center complexity, for rectal cancer it was detected that higher complexity (in public hospitals) was associated with a higher surgical risk for patients $(\mathrm{p}<0.001)$.

In $65.1 \%$ of cases an assessment of clinical TNM staging could not be found in the medical record. $\mathrm{pT}$ and $\mathrm{pN}$ were not identified either for $20.6 \%$ of cases (alive at discharge). Other variables that were also excluded from the analysis due to a high percentage ( $>20 \%$ ) of missing values were functional status assessment, height, urea, and classification of residual tumor. 
3,108 identified patients (retrospective and prospective phases)

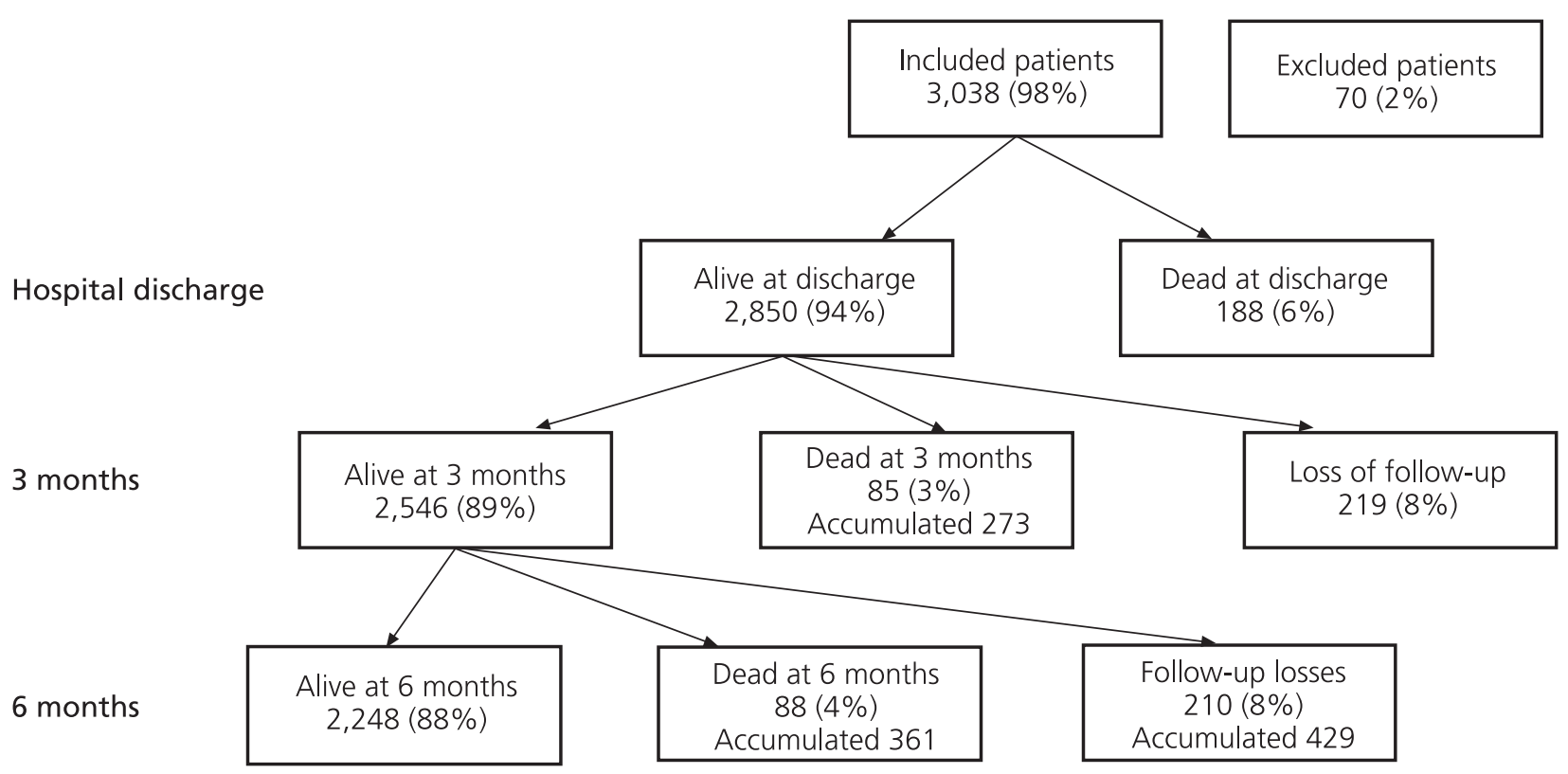

Fig. 2. Participation diagram.

Diagrama de participación.

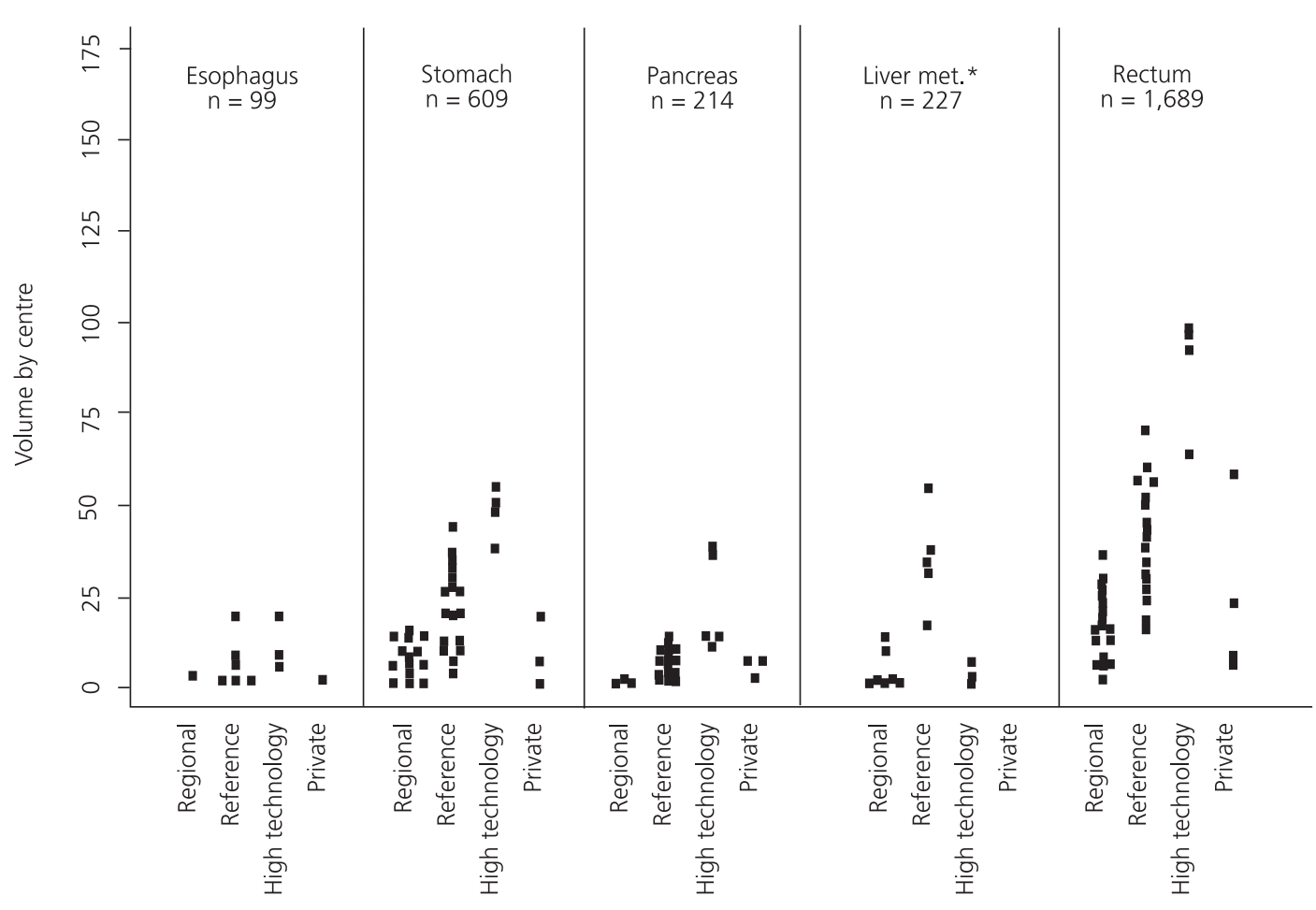

Fig. 3. Volume of procedures by level of complexity and type of cancer. *Met: metastases

Volumen de intervenciones según la complejidad del hospital y el tipo de cáncer. 
Table I. Characteristics of patients by type of cancer

\begin{tabular}{|c|c|c|c|c|c|}
\hline & Esophagus $(n=99)$ & Stomach $(n=809)$ & Pancreas $(n=214)$ & Liver m. $(n=227)$ & Rectum $(n=1,689)$ \\
\hline Age, mean (SD) & $63.0(9.7)$ & $68.7(12.5)$ & $64.8(11.4)$ & $63.4(11.3)$ & $68.3(12.0)$ \\
\hline Men, n (\%) & $91(92 \%)$ & $504(62 \%)$ & $120(56 \%)$ & $131(58 \%)$ & $1,094(65 \%)$ \\
\hline $\begin{array}{l}\text { Comorbidities, } \mathrm{n}(\%)^{\mathrm{a}} \\
\text { HT } \\
\text { COPD } \\
\text { Diabetes mellitus } \\
\text { CCI } \\
\text { Ischemic disease } \\
\text { CVA or other CV }\end{array}$ & $\begin{array}{c}25(25 \%) \\
29(29 \%) \\
10(10 \%) \\
6(6 \%) \\
9(9 \%) \\
4(4 \%) \\
\end{array}$ & $\begin{array}{l}285(36 \%) \\
149(18 \%) \\
128(16 \%) \\
77(10 \%) \\
102(13 \%) \\
60(8 \%) \\
\end{array}$ & $\begin{array}{c}80(38 \%) \\
20(9 \%) \\
49(23 \%) \\
22(10 \%) \\
14(7 \%) \\
10(5 \%) \\
\end{array}$ & $\begin{array}{c}60(28 \%) \\
24(11 \%) \\
26(12 \%) \\
12(6 \%) \\
13(6 \%) \\
12(6 \%) \\
\end{array}$ & $\begin{array}{l}694(42 \%) \\
314(19 \%) \\
291(18 \%) \\
206(13 \%) \\
197(12 \%) \\
136(8 \%) \\
\end{array}$ \\
\hline $\begin{array}{l}\text { Number of treated comor } \\
\text { None } \\
1 \text { or } 2 \\
3 \text { or more }\end{array}$ & $\begin{array}{c}53(54 \%) \\
38(38 \%) \\
8(8 \%) \\
\end{array}$ & $\begin{array}{l}342(42 \%) \\
349(43 \%) \\
118(15 \%) \\
\end{array}$ & $\begin{array}{l}104(49 \%) \\
82(38 \%) \\
28(13 \%) \\
\end{array}$ & $\begin{array}{c}119(52 \%) \\
88(39 \%) \\
20(9 \%) \\
\end{array}$ & $\begin{array}{l}701(42 \%) \\
697(41 \%) \\
291(17 \%) \\
\end{array}$ \\
\hline $\begin{array}{l}\text { ASA scale, } \mathrm{n}(\%)^{c} \\
\text { I-II } \\
\text { III } \\
\text { IV-V }\end{array}$ & $\begin{array}{c}38(38 \%) \\
53(54 \%) \\
4(4 \%) \\
\end{array}$ & $\begin{array}{c}428(53 \%) \\
286(35 \%) \\
43(5 \%) \\
\end{array}$ & $\begin{array}{c}117(55 \%) \\
80(37 \%) \\
4(2 \%) \\
\end{array}$ & $\begin{array}{c}99(44 \%) \\
106(47 \%) \\
8(4 \%) \\
\end{array}$ & $\begin{array}{c}951(56 \%) \\
565(33 \%) \\
80(5 \%) \\
\end{array}$ \\
\hline 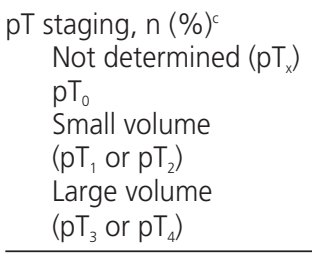 & $\begin{array}{l}29(29 \%) \\
47(48 \%) \\
\end{array}$ & $\begin{array}{l}289(36 \%) \\
338(42 \%) \\
\end{array}$ & $\begin{array}{l}55(26 \%) \\
94(44 \%) \\
\end{array}$ & -- & $\begin{array}{c}28(2 \%) \\
43(3 \%) \\
416(25 \%) \\
975(58 \%) \\
\end{array}$ \\
\hline $\begin{array}{l}\text { pN staging, } \mathrm{n}(\%)^{c} \\
\text { Not determined }\left(\mathrm{pN}_{\mathrm{x}}\right) \\
\mathrm{pN}_{0} \\
\text { Non regional }\left(\mathrm{pN}_{1}\right) \\
\text { Regional }\left(\mathrm{pN}_{2} \circ \mathrm{pN}_{3}\right)\end{array}$ & $\begin{array}{c}4(4 \%) \\
31(31 \%) \\
28(28 \%) \\
16(16 \%)\end{array}$ & $\begin{array}{c}34(4 \%) \\
231(29 \%) \\
192(24 \%) \\
194(24 \%)\end{array}$ & $\begin{array}{c}23(11 \%) \\
63(29 \%) \\
70(33 \%) \\
2(1 \%)\end{array}$ & -- & $\begin{array}{c}64(4 \%) \\
808(48 \%) \\
333(20 \%) \\
227(13 \%)\end{array}$ \\
\hline
\end{tabular}

SD: standard deviation; HT: hypertension; COPD: chronic obstructive pulmonary disease; CCl: congestive cardiac insufficiency; CVA: cerebrovascular accident; CV: cerebrovascular; ASA: American Society of Anesthesiology; pT: extension of tumor; pN: extension of dissemination to lymph nodes; Liver m.: liver metastases.

'Multiresponse variable, the percentage represents the \% of patients with at least that particular comorbidity; ${ }^{\circ}$ Ischemic heart disease; 'Percentage calculated over the total, the sum up to $100 \%$ represents the percentage of lost cases.

\section{Characteristics of the healthcare process}

The diagnostic tests applied, as well as the use of neoadjuvant and adjuvant radiation therapy and/or chemotherapy, depended mainly on the type of cancer (Table II), and variations resulting from center complexity were observed in only some of them. In rectal cancer, the use of diagnostic tests was different in regional hospitals (decreased use of computerized tomography and increased use of abdominal ultrasounds $(\mathrm{p}<0.001)$ and in private hospitals (decreased use of colonoscopy, p < 0.001), in comparison with the rest. Similarly, in stomach cancer regional hospitals made more use of abdominal ultrasounds $(\mathrm{p}<0.001)$ and private hospitals used less computerized tomography and esophagogastroscopy $(\mathrm{p}<$ $0.001)$. In rectal cancer and liver metastases variability was observed in primary treatments, the application of which was more frequent in centers with a higher level of complexity and less frequent in private hospitals $(\mathrm{p}<$ $0.001)$.
In terms of surgical technique, private centers primarily applied anterior resection with anastomosis in rectal cancer $(73 \%, \mathrm{p}=0.001)$, and partial gastrectomies in stomach cancer $(88 \%, \mathrm{p}<0.05)$. The latter technique was also more frequent in less complex public hospitals $(\mathrm{p}=$ 0.07). For esophageal cancer, thoracoabdominal esophagectomy was more frequent in high-technology centers and cervicoabdominal esophagectomy was more frequent in reference centers $(\mathrm{p}<0.001)$. Mean hospital stay ranged from 10 to 23 days, length being shorter for stomach and rectal cancer as well as for liver metastases $(\mathrm{p}<0.001)$.

\section{Outcomes of care}

The most frequent complications during hospital stay were systemic or general complications given that they presented in over $40 \%$ of cases - especially renal complications $(16.5 \%)$, except for esophageal cancer, in which 
Table II. Characteristics of the healthcare process by type of cancer

\begin{tabular}{|c|c|c|c|c|c|}
\hline & Esophagus $(n=99)$ & Stomach $(n=809)$ & Pancreas $(n=214)$ & Liver m. $(n=227)$ & Rectum $(n=1,689)$ \\
\hline $\begin{array}{l}\text { Reason for admission, } \mathrm{n}(\%) \\
\text { Scheduled } \\
\text { Urgent }\end{array}$ & $\begin{array}{l}86(87 \%) \\
13(13 \%)\end{array}$ & $\begin{array}{l}647(80 \%) \\
162(20 \%)\end{array}$ & $\begin{array}{c}136(64 \%) \\
78(36 \%)\end{array}$ & $\begin{array}{c}218(96 \%) \\
9(4 \%)\end{array}$ & $\begin{array}{c}1,461(87 \%) \\
224(13 \%)\end{array}$ \\
\hline $\begin{array}{l}\text { Number of diagnostic tests, n (\%) } \\
1 \\
2 \\
3 \text { or more }\end{array}$ & $\begin{array}{c}0(0 \%) \\
14(14 \%) \\
85(86 \%) \\
\end{array}$ & $\begin{array}{c}4(1 \%) \\
437(54 \%) \\
368(45 \%)\end{array}$ & $\begin{array}{c}2(1 \%) \\
103(48 \%) \\
109(51 \%) \\
\end{array}$ & $\begin{array}{c}4(2 \%) \\
152(67 \%) \\
71(31 \%)\end{array}$ & $\begin{array}{c}33(2 \%) \\
712(42 \%) \\
944(56 \%)\end{array}$ \\
\hline Computerized tomography, n (\%) & $99(100 \%)$ & $663(82 \%)$ & $201(94 \%)$ & $208(92 \%)$ & $1,267(75 \%)$ \\
\hline Esophagogastroscopy, n (\%) & $97(98 \%)$ & $774(96 \%)$ & - & - & - \\
\hline Esophagogastroduodenal transit, n (\%) & $57(58 \%)$ & - & - & - & - \\
\hline Abdominal ultrasounds, n (\%) & - & $246(30 \%)$ & $147(69 \%)$ & $69(30 \%)$ & $614(36 \%)$ \\
\hline Magnetic resonance imaging, $\mathrm{n}(\%)$ & - & - & $77(36 \%)$ & $72(32 \%)$ & - \\
\hline Colonoscopy, n (\%) & - & - & - & - & $1,534(91 \%)$ \\
\hline Neoadjuvant radiation therapy ${ }^{a}, \mathrm{n}(\%)$ & $15(16 \%)$ & $1(0 \%)$ & $1(1 \%)$ & $6(3 \%)$ & $307(18 \%)$ \\
\hline Neoadjuvant chemotherapyà, n (\%) & $20(20 \%)$ & $13(2 \%)$ & $2(1 \%)$ & $45(20 \%)$ & $283(17 \%)$ \\
\hline $\begin{array}{l}\text { Surgical technique }{ }^{\mathrm{abc}}, \mathrm{n}(\%) \\
\text { Technique } \mathrm{A} \\
\text { Technique B } \\
\text { Technique C } \\
\text { Palliative surgery }\end{array}$ & $\begin{array}{l}25(25 \%) \\
39(39 \%) \\
13(13 \%) \\
7(7 \%) \\
\end{array}$ & $\begin{array}{c}248(31 \%) \\
445(55 \%) \\
- \\
73(9 \%) \\
\end{array}$ & $\begin{array}{l}142(66 \%) \\
13(6 \%) \\
15(7 \%) \\
37(17 \%) \\
\end{array}$ & $\begin{array}{l}80(35 \%) \\
62(27 \%) \\
25(11 \%) \\
14(6 \%) \\
\end{array}$ & $\begin{array}{c}256(15 \%) \\
180(11 \%) \\
813(48 \%) \\
151(9 \%) \\
\end{array}$ \\
\hline Red blood cell bags ${ }^{\mathrm{a}}(\geq 1), \mathrm{n}(\%)$ & $33(33 \%)$ & $264(33 \%)$ & $101(47 \%)$ & $59(26 \%)$ & $364(22 \%)$ \\
\hline Surgical time (h), median (IQR) & $4,6(1,7)$ & $3,0(1,3)$ & $4,7(1,8)$ & $3,8(1,5)$ & $2,8(2,5)$ \\
\hline Adjuvant radiation therapy ${ }^{\mathrm{a}}, \mathrm{n}(\%)$ & $29(17 \%)$ & $259(16 \%)$ & $93(37 \%)$ & $134(21 \%)$ & $823(29 \%)$ \\
\hline Adjuvant chemotherapy ${ }^{a}, \mathrm{n}$ (\%) & $26(26 \%)$ & $255(32 \%)$ & $90(42 \%)$ & $134(59 \%)$ & $780(46 \%)$ \\
\hline Stay (days), median (IQR) & $20(22)$ & $16(17)$ & $23(19)$ & $10(6)$ & $13(11)$ \\
\hline
\end{tabular}

Liver m.: liver metastases: IQR: interquartile range.

aPercentage calculated over the total; ${ }^{b}$ In $12.8 \%$ of cases the technique was not available (esophagus $15 \%$, stomach $5 \%$, pancreas $7 \%$, liver metastases $20 \%$, rectum $17 \%)$; 'For esophagus cancer: technique $\mathrm{A}=$ thoracoabdominal esophagectomy, technique $\mathrm{B}=$ cervicoabdominal esophagectomy, technique $\mathrm{C}=$ cervicothoracoabdominal esophagectomy; for stomach cancer, technique $A=$ total gastrectomy, technique $B=$ partial gastrectomy; for pancreas cancer, technique $A=$ cephalical duodeno-pancreatectomy, technique $\mathrm{B}=$ corporo/caudal pancreatectomy, technique $\mathrm{C}=$ total duodenopancreatectomy; for liver metastases: technique $\mathrm{A}=$ segmentectomy, technique $\mathrm{B}=$ hepatectomy, technique $C=$ other hepatectomies; for rectal cancer: technique $A=$ abdominoperineal resection (Miles), technique $B=$ anterior resection (Hartmann), technique $\mathrm{C}=$ anterior resection with anastomosis.

most frequent complications were pulmonary complications $(45.5 \%)-$. Complications until discharge resulting from surgical technique and surgical wounds (local) developed in $24.0 \%$ and $18.1 \%$ of patients, respectively (Fig. 4A). Differences were observed depending on hospital complexity level, with the \% of general complications $(\mathrm{p}<0.0001)$ and wound-related complications $(\mathrm{p}=$ 0.001 ) being lower in high-technology centers (in private hospitals, only in the case of general complications) when compared to others.

Relapses at $3(5.6 \%)$ and 6 months $(11.2 \%)$ varied depending on type of cancer (Fig. 4B). The frequency of reinterventions until discharge $(9.9 \%)$ and at 6 months (17.8\%) also varied in terms of type of cancer (Fig. 4C). Repeat procedures in rectal cancer were more frequent in centers with higher complexity, and reached the highest rate in private hospitals, both at 3 and 6 months $(20.7 \%$ and $30.2 \%$, respectively, $\mathrm{p}<0.01)$.

Gross (non-adjusted) intrahospital surgical mortality ranged from $2.6 \%$ for liver metastases to $18.2 \%$ for esophageal cancer, approximately doubling that of almost all types of cancer at 6 months (Fig. 4D). Only in the case of stomach cancer did the center's complexity level appear to be associated with mortality at 6 months after adjusting for patient age and ASA ( $p<0.01)$, with hightechnology hospitals exhibiting the best results.

\section{DISCUSSION}

This study has attempted to describe the profile of patients who have undergone surgery for digestive cancer, their healthcare process and short-mid-term outcomes, in many hospitals that perform this type of surgery in Catalonia. Only procedures with a significant impact on quality of life and which are considered tertiary (presenting high technological complexity and a large number of requirements relating to structural resources or level of expertise in professionals) have been included. Overall, no differences were observed in terms of the characteris- 
(A) Complications until discharge

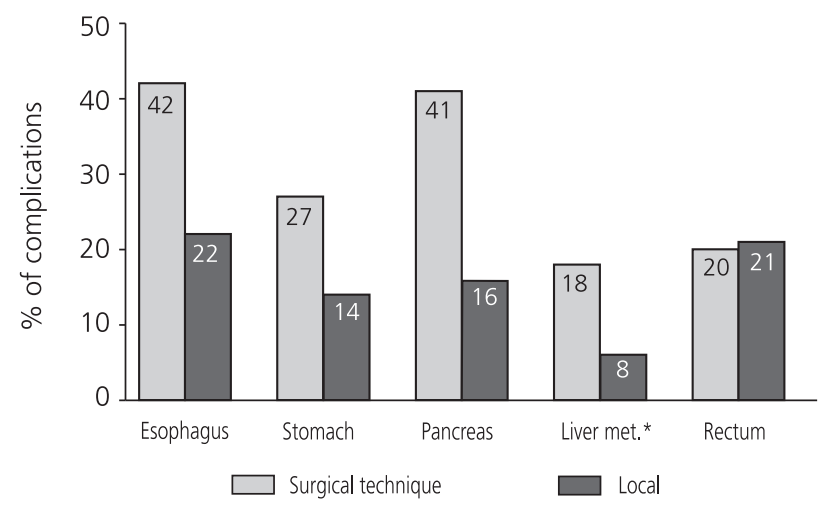

(C) Re-interventions

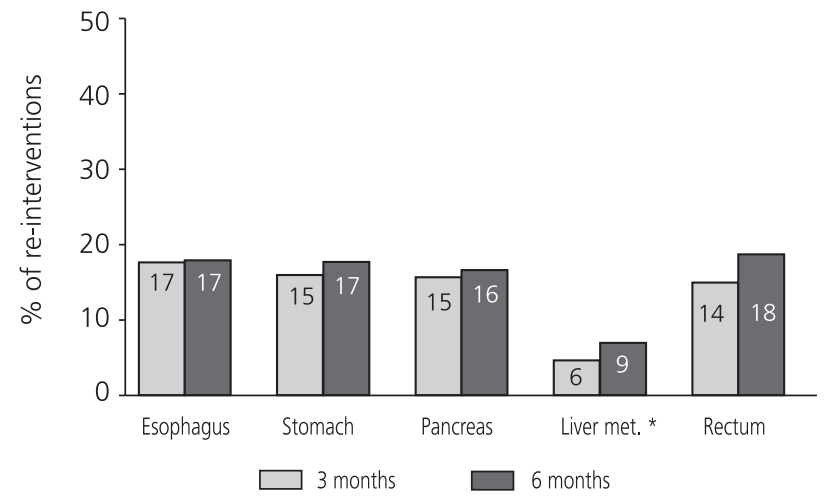

(B) Relapses

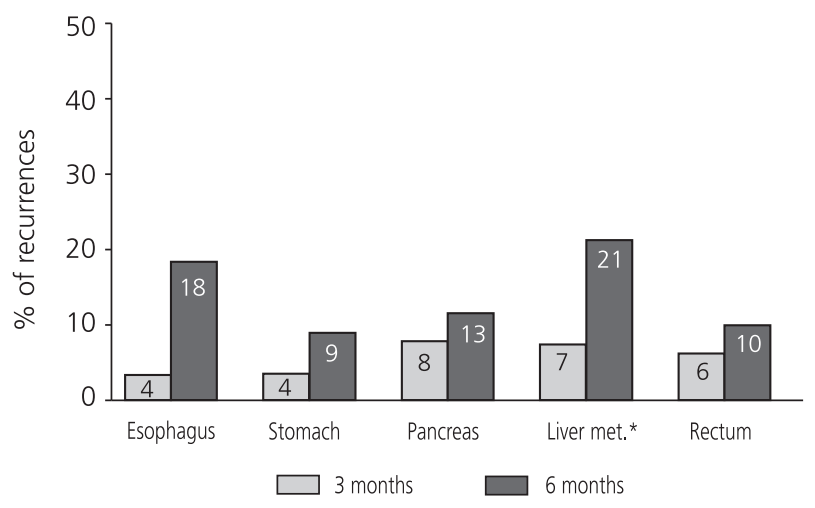

(D) Survival

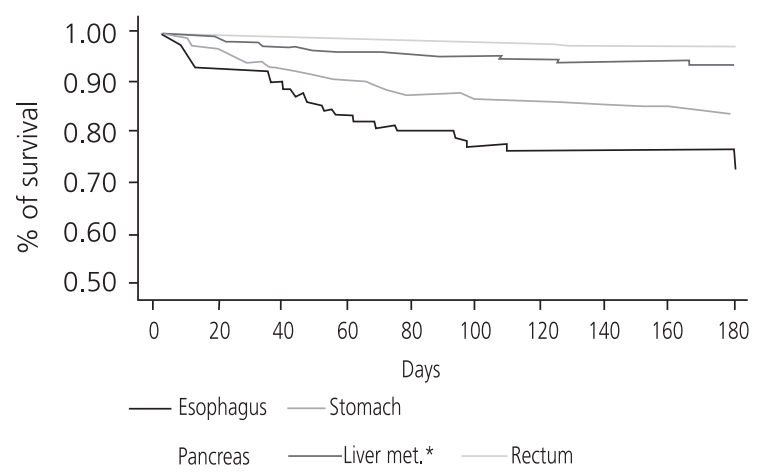

Fig. 4. A. Complications until discharge; B. Relapses; C. Re-interventions; and D. Survival by type of cancer (non-adjusted accumulated incidence/survival curves). *met.: metastases.

A. Complicaciones hasta el alta; B. Recidivas; C. Reintervenciones; y D. Supervivencia según el tipo de cáncer (curvas de incidencia/supervivencia acumulada no ajustada).

tics of operated patients by center complexity level, but clinical-pathological staging and other functional status variables could not be analyzed due to a high percentage of missing values. Healthcare process characteristics and outcomes were, generally speaking, as expected, except for the high mortality at discharge and at 6 months' follow-up in esophageal cancer, and for the frequency of complications and re-interventions in the different types of surgery assessed.

These results differ from other published results - both in Spain and in other developed countries $(8,17-29)$ - and can be explained, only in part, by the inclusion of palliative and emergency procedures (also by the sealing of colostomy in patients who have undergone a procedure using the Hartmann technique in rectal cancer), even though the differences in characteristics of the series included should also be taken into account (30). The high relapse rate at 6 months' follow-up occurred especially in palliative surgery cases, and the possibility that they could really be a progression of the disease could not be ruled out. However, some of these results do not reach the standards proposed in our setting (31).

The variability identified in some aspects of the process did not translate into different outcomes according to hospital complexity, except in the case of rectal cancer, for re-interventions, and in stomach cancer, for mortality. However, clear practice patterns or styles during the healthcare process that explain this phenomenon have not been identified. In both types of cancer the performance of diagnostic tests showed a similar pattern, 
with a tendency to performing fewer tests in private hospitals and using less complex tests (abdominal ultrasounds) in regional hospitals. A similar behavior was also observed in these types of cancer in terms of the radicality of the surgical technique and center complexity: fewer total gastrectomies and fewer resections with colostomy in private centers when compared to public hospitals, and, within these, in those presenting lesser complexity (only for stomach cancer).

Furthermore, in rectal cancer, as the number of procedures per center increased, the variability in the percentage of sphincter preserving surgery (without colostomy) decreased, as was expected, and leaned towards $70 \%$ of cases (except in one center) $(17,21-23)$. However, this pattern was not observed for stomach cancer, where variability in radicality was significant for any volume of procedures, even in centers with a larger volume (25 to $68 \%$ of total gastrectomies). In other less frequent types of cancer, despite the existence of variability in the process and outcomes by level of center complexity, no statistically significant differences were observed, probably due to the limited statistical power of the analyses.

However, there was high variability in the volume of procedures performed in each center for all types of cancer, especially in reference hospitals. Given that a large volume of procedures does not always guarantee good results $(8,32)$, and that there may be determining process and structure factors, it seems the most reasonable option before recommending any change in care would be to develop risk adjustment models that adequately include patient severity (33) and take into account different structure factors for the study of identified variations in process and outcomes. This study would enable the definition of these models, but a series of possible limitations should be taken into account.

The first limitation identified is the lack of standardization and absence of relevant information (staging, functional status, some aspects of the surgical technique) in the medical record, the main source of information. This entails a lesser capacity to adequately adjust patient severity or risk and the healthcare process but highlights the importance of obtaining and including these data in the medical record (or in other information tools/systems) in order to assess the effectiveness of clinical practice.

Additionally, the aforementioned limitation and the possible variability in this process due to the collaboration of several professionals (practically a different person in each center) may have decreased the validity and reliability of the information. However, when comparing common variables pertaining to our study and hospital discharge MBDS no differences were reported (data not shown).

Finally, the follow-up of outcomes was limited to 6 months after surgery. For some of the types of cancer studied this 6-month follow-up may be a fairly short period for the assessment of outcomes, but it represents a significant advancement over the majority of studies that limit their analyses to the in-hospital period, especially those based on hospital discharge MBDS.

\section{ACKNOWLEDGEMENTS}

This study has been partially funded by the Carlos III Health Institute by means of the Programme for Promotion of Biomedical and Health Sciences Research, which offers funding for research projects (03/1641) and for the performance of research studies on health technology assessment (05/90185). We would also like to thank the Cooperative Cancer Research Network (RD06/0020/0089). The Generalitat of Catalonia has recognized the Agency for Health Technology Assessment and Research as a research group in Assessment of Health services and Outcomes (2009SGR 1317).

The authors would like to thank Júlia López and Mercè Salvat for their collaboration during the study's field work, and all professionals who participated in collecting data from the hospitals that took part in the study.

\section{*ONCOrisc Study Group:}

\section{Advisory Committee}

Antoni Anglada (H. de Vic, Barcelona); Manuel Armengol, Josep Tabernero (H. General Vall d'Hebron, Barcelona); Pedro Barrios (H. General de l'Hospitalet, Barcelona); Jordi Boix (CatSalut); Marc Antoni Broggi, Jaume Fernández-Llamazares (H. Universitari Germans Trias i Pujol, Badalona, Barcelona); José A. Carceller, Joan Viñas (H. Univ. Arnau de Vilanova, Lleida); Ferran Caballero (H. Comarcal Alt Penedès, Vilafranca del Penedès, Barcelona); Juan José Calvo (H. Comarcal Móra d'Ebre, Tarragona); Antoni Castells, Laureano Fernández-Cruz, Pere Gascon (H. Clínic i Provincial, Barcelona), Luis Grande, Rafael Manzanera, Antoni Sitges, Jordi Varela (H. del Mar, Barcelona); Xavier Castells, Francesc Macià (IMAS, Barcelona), Jaume Estany (Consorci Sanitari de Barcelona); Antonio Codina, Joan Figueras $(\mathrm{H}$. Universitari Dr. Josep Trueta, Girona); Joan Martí Ragué (Ciutat Sanitària i Universitària de Bellvitge, Hospitalet, Barcelona); Constancio Marco (H. Mútua de Terrassa, Barcelona); Santiago Nofuentes (Consorci Integral de l'Hospitalet, Barcelona); Eugeni Saigí (Corporació Sanitària Parc Taulí, Sabadell, Barcelona); Josepa Ribes (H. Duran i Reynals, Hospitalet, Barcelona); Rosa Solà (Universitat Rovira i Virgili, Tarragona); Manuel Trias (H. de la Santa Creu i Sant Pau, Barcelona).

\section{Cooperative Group}

Roser Cid (H. de Barcelona); Federico Madrid (Centro Médico Teknon, Barcelona); Josep Domingo (H. de 
Figueres, Girona), Lluis Pérez Ruiz (H. Universitari Arnau de Vilanova, Lleida); Francisco García Borobia (Ciutat Sanitària Univ. de Bellvitge, Hospitalet, Barcelona); Josep Maria Badia (H. General Granollers, Barcelona); Felip Pi (H. de Viladecans, Barcelona); Jordi Pié (H. Municipal de Badalona, Barcelona); Josep Maria Pueyo (Consorci Sanitari Integral - H. Dos de Maig, Barcelona); Pere Puig (H. Sant Jaume, Calella, Barcelona); Enric Quintanilla (Serveis Integral del Baix Empordà, H. de Palamos, Girona); Xavier Rodamilans (H. Provincial Santa María, Lleida); Joan Sala (Consorci Sanitari de Terrassa, Barcelona); Baltasar Sanmartí (H. Comarcal de la Selva, Girona); José Segura (H. General de Mollet, Barcelona); Constantí Serra (H. General de Vic, Barcelona); Rosa María Servent (H. Comarcal de Sant Bernabé, Berga, Barcelona); Xavier Sunyol (Consorci Sanitari Mataró, Barcelona); Jordi Serra (H. Comarcal del Pallars, Lleida); Manel Trias (H. de la Santa Creu i Sant Pau, Barcelona); Joan Urgellès ( $\mathrm{H}$. de Sant Boi, Barcelona); Josep Verge (H. Residència Sant Camil, Sant Pere de Ribes, Barcelona); Joan Aixàs (Fundació Sant Hospital, La Seu d'Urgell, Lleida); Pedro Barrios (Consorci Sanitari Integral - Hospital General de l'Hospitalet, Barcelona); Marc Antoni Broggi (H. Univ. Germans Trias i Pujol, Badalona, Barcelona); Jordi Caballé (Centre Hospitalari de Manresa, Barcelona); Ferran Caballero (H. Comarcal de l'Alt Penedès, Vilafranca del Penedès, Barcelona); Juan José Calvo (H. Comarcal Móra d'Ebre, Tarragona); Enric Caubet (H. Sant Pau i Santa Tecla, Tarragona); Antoni Codina (H. Universitari Dr. Josep Trueta, Girona); Daniel del Castillo (H. Universitari Sant Joan de Reus, Tarragona); Fernando Doncel (Hospital General de Catalunya, Sant Cugat del Vallès, Barcelona); Juan Carlos Garcia-Valdecasas (H. Clínic i Provincial, Barcelona); Miquel Fernández Layos (H. General de Manresa, Barcelona); Enrique Fernández Sallent (Fundació Sanitària Igualada-H. General d'Igualada, Barcelona); Javier Foncillas (H. Quinta de Salut l'Aliança - Sagrat Cor, Barcelona); Rosa Fradera (Pius H. de Valls, Tarragona); Salvador Navarro (Consorci Hospitalari Parc Taulí, Sabadell, Barcelona); Antoni Gil (H. Sant Joan de Déu de Martorell, Barcelona); Luis Grande (H. del Mar, Barcelona); Manuel Martínez Brey (H. de Tortosa Verge de la Cinta, Tarragona); Josep Maria Greoles (Clínica de Ponent, Lleida); Marta Lahuerta (H. de Sant Rafael, Barcelona); Ferran López Lanao (H. Provincial Santa Caterina, Girona); Luis Luengo (H. Universitari Joan XXIII, Tarragona); Constancio Marco (H. Mútua de Terrassa, Barcelona); Joaquim Martínez Puig (H. Sant Jaume d'Olot, Girona); Lluis Masferrer (Consorci Sanitari Integral l' Hospitalet, Barcelona); Didac Miró (H. de Sant Celoni Fundació Privada, Barcelona); Joan Valverde (H. de l'Esperit Sant, Santa Coloma, Barcelona); Manel Armengol (H. Universitari Vall d 'Hebron, Barcelona); Joan Torralba (Institut Universitari Dexeus, Barcelona); Xavier Piulachs (Clínica Plató Fundació Privada, Barcelona); Francesc Tuca (Clínica Girona, S.L., Girona).

\section{REFERENCES}

1. Luft HS, Bunker JP, Enthoven AC. Should operations be regionalized? The empirical relation between surgical volume and mortality. N Engl J Med 1979; 301(25): 1364-9.

2. Luft HS, Hunt SS, Maerki SC. The volume-outcome relationship: practice-makes-perfect or selective-referral patterns? Health Serv Res 1987; 22(2): 157-82.

3. Bentrem D, Brennan M. Outcomes in oncologic surgery: does volume make a difference? World J Surg 2005; 29(10): 1210-6.

4. Grande L. Subespecialización y calidad asistencial en la cirugía de las resecciones hepáticas. Cir Esp 2005; 78(1): 1-2.

5. McArdle C. ABC of colorectal cancer: primary treatment-does the surgeon matter? BMJ 2000; 321(7269): 1121-3.

6. Steele RJ. The influence of surgeon case volume on outcome in sitespecific cancer surgery. Eur J Surg Oncol 1996; 22(3): 211-3.

7. Martínez-Ramos D, Escrig-Sos J, Miralles-Tena JM, Rivadulla-Serrano MI, Daroca-José JM, Salvador Sanchís JL. Influencia de la especialización del cirujano en los resultados tras cirugía por cáncer de colon. Utilidad de los índices de propensión (propensity scores). Rev Esp Enferm Dig 2008; 100(7): 387-92.

8. Pla R, Pons JMV, González JR, Borràs JM. ¿Influye en el proceso y en los resultados el volumen de procedimientos en la cirugía del cáncer? Análisis basado en datos clínico-administrativos. Cir Esp 2004; 75(4): 179-88.

9. Khuri S, Henderson W. The case against volume as a measure of quality of surgical care. World J Surg 2005; 29(10): 1222-9.

10. Donabedian A. Quality assessment and assurance: unity of purpose, diversity of means. Inquiry 1988; 25: 173-92.

11. Hammermesiter KE, Shroyer L, Sethi G, Grover FL. Why it is important to demonstrate linkages between outcomes of care and process and structures of care. Med Care 1995; 33: OS5-OS16.

12. Katz MH. Multivariable analysis: a primer for readers of medical research. Ann Intern Med 2003; 138(8): 644-50.

13. Karnofsky DA, Abelman WH, Craver LF, Burchenal JH. The use of nitrogen mustards in palliative treatment of carcinoma. Cancer 1948; 1: 634-56.

14. Teasdale G, Jennett B. Assessment and prognosis of coma after head injury. Acta Neurochir (Wien) 1976; 34(1-4): 45-55.

15. American College of Surgeons Committee on Trauma. Advanced trauma life support student manual. $6^{\text {th }}$ ed. Chicago, IL (US): American College of Surgeons; 1997.

16. Dripps RD, Lamont A, Eckenhoff J. The role of anesthesia in surgical mortality. JAMA 1961; 178: 261-6.

17. Ortiz H. Estándares de calidad e instrumentación necesaria en la cirugía del cáncer de recto bajo. Cir Esp 2003; 74: 321-4.

18. López P, Alcalde J, Rodríguez-Cuéllar E, Landa I, Jaurrieta E. Proyecto nacional para la gestión clínica de procesos asistenciales. Tratamiento quirúrgico del cáncer colorrectal I. Aspectos generales. Cir Esp 2002; 71: 173-80.

19. Ramírez-Rodríguez J, Aguilella-Diago V. Recidiva local en el cáncer de colon y recto. Cir Esp 2005; 78: 344-50.

20. Fernández JA, Parrilla P. ¿Cuáles son los principales errores que cometemos los cirujanos en el tratamiento del cáncer de páncreas? Cir Esp 2006; 79(4): 215-23.

21. Martling AL, Holm T, Rutqvist LE, Moran BJ, Heald RJ, Cedemark B. Effect of a surgical training programme on outcome of rectal cancer in the County of Stockholm. Stockholm Colorectal Cancer Study Group, Basingstoke Bowel Cancer Research Project. Lancet 2000; 356(9224): 93-6.

22. Wibe A, Moller B, Norstein J, Carlsen E, Wiig JN, Heald RJ, et al. A national strategic change in treatment policy for rectal cancer--implementation of total mesorectal excision as routine treatment in Norway. A national audit. Dis Colon Rectum 2002; 45(7): 857-66.

23. Kapiteijn E, Putter H, van de Velde CJ. Impact of the introduction and training of total mesorectal excision on recurrence and survival in rectal cancer in The Netherlands. Br J Surg 2002; 89(9): 1142-9.

24. González-González JJ, Sanz-Álvarez L, Marques-Álvarez L, Navarrete-Guijosa F, Martínez-Rodríguez E. Complicaciones de la cirugía de exéresis del cáncer de esófago. Cir Esp 2006; 80(6): 349-60.

25. Butte JM, Duarte I, Crovari F, Guzmán S, Llanos O. Cáncer gástrico en pacientes mayores de 75 años. Tratamiento quirúrgico y supervivencia a largo plazo. Cir Esp 2007; 82(6): 341-5. 
Annex. Types of cancer and surgical procedures selected according to ICD-9 codes in the hospital discharge HDMBDS

\begin{tabular}{|c|c|c|c|}
\hline Primary diagnosis & $I C D-9$ & First procedure & ICD-9 \\
\hline Malignant neoplasm of the esophagus & $150(150.0-150.9)$ & $\begin{array}{l}\text { Esophageal excision } \\
\text { Unspecified esophagectomy } \\
\text { Partial esophagectomy } \\
\text { Total esophagectomy }\end{array}$ & $\begin{array}{l}42.4 \\
42.40 \\
42.41 \\
42.42\end{array}$ \\
\hline Malignant neoplasm of the stomach & $151(151.0-151.9)$ & $\begin{array}{l}\text { Partial gastrectomy with esophageal anastomosis } \\
\text { Proximal gastrectomy } \\
\text { Partial gastrectomy with duodenal anastomosis } \\
\text { Distal gastrectomy } \\
\text { Gastro-pylorectomy } \\
\text { Billroth's surgery II } \\
\text { Partial gastrectomy with jejunal anastomosis } \\
\text { Billroth's surgery II } \\
\text { Other partial gastrectomies } \\
\text { Partial gastrectomy with jejunal transposition } \\
\text { Henley's jejunal transposition } \\
\text { Others } \\
\text { Partial gastrectomy with gastric bypass-gastrostomy } \\
\text { Segmental resection of the stomach } \\
\text { Total gastrectomy } \\
\text { Total gastrectomy with intestinal interposition } \\
\text { Other total gastrectomies } \\
\text { Esophago-duodenostomy with total gastrectomy } \\
\text { Esophago-gastrectomy NOS } \\
\text { Esophago-jejunostomy with total gastrectomy } \\
\text { Radical gastrectomy } \\
\text { Total gastro-duodenectomy }\end{array}$ & $\begin{array}{r}43.7 \\
43.8 \\
43.81 \\
43.89\end{array}$ \\
\hline $\begin{array}{l}\text { Malignant neoplasm of the rectum, } \\
\text { rectum-sigmoid and anus junction }\end{array}$ & $154(154.0-154.8)$ & $\begin{array}{l}\text { Resection and/or colostomy } \\
\text { Resection without colostomy }\end{array}$ & $\begin{array}{c}45.76 \\
46.1 \\
48.5 \\
48.62 \\
45.8 \\
48.6\end{array}$ \\
\hline Malignant neoplasm of the pancreas & $\begin{array}{l}157(157.0-157.9 \\
\left.\text { except } 157.4^{*}\right)\end{array}$ & Partial pancreatectomy & 52.5 \\
\hline & & $\begin{array}{l}\text { Proximal pancreatectomy } \\
\text { Excision of the head of the pancreas (with part of the body) } \\
\text { Proximal pancreatectomy with simultaneous duodenectomy }\end{array}$ & 52.51 \\
\hline & & $\begin{array}{l}\text { Distal pancreatectomy } \\
\text { Excision of the head of the pancreas (with part of the body) } \\
\text { Subtotal radical pancreatectomy } \\
\text { Other partial pancreatectomies } \\
\text { Total pancreatectomy } \\
\text { Pancreatectomy with simultaneous duodenectomy } \\
\text { Radical pancreaticoduodenectomy } \\
\text { Whipple's procedure } \\
\text { Pancreaticoduodenal resection in two stages (first stage) } \\
\text { (second stage) } \\
\text { Pancreaticoduodenal resection in one stage with choledochal-jejunal } \\
\text { anastomosis, pancreatico-jejunal anastomosis and gastrojejunostomy } \\
\text { Radical resection of the pancreas }\end{array}$ & $\begin{array}{c}52.52 \\
52.53 \\
52.59 \\
52.6 \\
52.7\end{array}$ \\
\hline Malignant neoplasm of Vater's ampulla & 156.2 & Excision of Vater's ampulla (with choledochous reimplantation) & 51.62 \\
\hline \multirow[t]{2}{*}{$\begin{array}{l}\text { Secondary malignant neoplasm of the liver } \\
\text { (liver metastases) }\end{array}$} & 197.7 & $\begin{array}{l}\text { Partial hepatectomy } \\
\quad \text { Cuneiform liver resection }\end{array}$ & 50.22 \\
\hline & & $\begin{array}{l}\text { Liver lobectomy } \\
\text { Total liver lobectomy with partial excision of another lobe } \\
\text { Total hepatectomy }\end{array}$ & $\begin{array}{l}50.3 \\
50.4\end{array}$ \\
\hline
\end{tabular}

*Islets of Langerhans; ICD-9: International Classification of Diseases $9^{\text {th }}$ revision; HDMBDS: Hospital Discharge Minimum Basic Data Set. 
26. Codina-Cazador A, Espín E, Biondo S, Luján J, de Miguel M, Alós R, et al. Proceso docente auditado del tratamiento del cáncer de recto en España: resultados del primer año. Cir Esp 2007; 82(4): 209-13.

27. Cunningham SC, Kamangar F, Kim MP, Hammoud S, Haque R, Maitra A, et al. Survival after gastric adenocarcinoma resection: eighteen-year experience at a single institution. J Gastrointest Surg 2005; 9(5): 718-25.

28. Llanos O, Guzmán S, Pimentel F, Ibáñez L, Duarte I. Results of surgical treatment of gastric cancer. Dig Surg 1999; 16(5): 385-8.

29. Parrilla Paricio P, García Marcilla JA, Ortiz Escandell MA, Martínez de Haro L, Castellanos Escrig G. Resultados del tratamiento quirúr- gico del cáncer de esófago (209 casos). Rev Esp Enferm Dig 1994; 85(3): 161-7.

30. McCulloch P, Ward J, Tekkis PP. Mortality and morbidity in gastrooesophageal cancer surgery: initial results of ASCOT multicentre prospective cohort study. BMJ 2003; 327(7425): 1192-7.

31. Informe sobre el Proyecto Nacional para la Gestión Clínica de Procesos Asistenciales. Tratamiento quirúrgico del cáncer colorrectal (II). Desarrollo de la vía clínica. Cir Esp 2003; 74: 206-20.

32. Jaurrieta-Mas E. Concentración de procedimientos quirúrgicos en la cirugía oncológica. Cir Esp 2004; 75: 165-6.

33. Pons JMV. El ajuste del riesgo en la medida de los resultados de la cirugía cardiaca. Cir Cardiov 1997; 4(1): 4-14.

\title{
Proceso asistencial y resultados en la cirugía de cáncer digestivo: diseño y resultados iniciales de un estudio de cohortes multicéntrico
}

\author{
M. Espallargues ${ }^{1,2}$, C. Almazán ${ }^{1,2}$, C. Tebé ${ }^{1,2}$, R. Pla ${ }^{3}$, J. M. V. Pons ${ }^{1,2}$, E. Sánchez ${ }^{1,2}$, M. Mias ${ }^{1,2}$, \\ S. Alomar ${ }^{1}$ y J. M. Borràs ${ }^{4}$, por el Grupo de Estudio ONCOrisc**

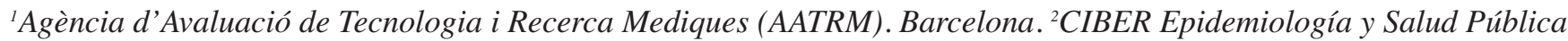 \\ (CIBERESP). España. ${ }^{3}$ Hospital Universitari de Bellvitge. Hospitalet de Llobregat, Barcelona. ${ }^{4}$ Pla Director \\ d'Oncologia. Institut Català d'Oncologia. Barcelona
}

\section{RESUMEN}

Antecedentes: la mayoría de estudios que analizan la influencia de factores de estructura sobre los resultados son retrospectivos, realizados con bases de datos clínico-administrativas y basados principalmente en el volumen de intervenciones.

Objetivo: estudiar la variabilidad en el proceso y los resultados de la cirugía oncológica de esófago, estómago, páncreas, metástasis hepáticas y recto en Cataluña, así como los factores asociados a esta.

Pacientes y método: estudio de cohortes multicéntrico retrospectivo (2002) y prospectivo (2003-05). Se recogió información sobre el paciente, el proceso y los resultados de la atención previamente a la cirugía, al alta, y a los 3 y 6 meses.

\footnotetext{
*Al final de la versión en inglés del artículo se indican los componentes del Grupo de Estudio ONCOrisc (Avaluació del procediment terapèutic i els seus resultats en oncologia digestiva).
}

Resultados: participaron 49 (80\%) hospitales en la etapa retrospectiva, de los cuales 44 (90\%) prosiguieron en la prospectiva. Se incluyeron 3.038 pacientes (98\%). No se observaron diferencias en el perfil de pacientes operados según el nivel de complejidad del hospital pero no se pudo analizar el estadiaje clínico-patológico y otras variables de estado funcional por presentar más del $20 \%$ de valores ausentes. Existió una variabilidad importante en el volumen de intervenciones por centro así como en algunos aspectos del proceso asistencial según el tipo de cáncer y la complejidad del centro. Se identificaron elevadas tasas de mortalidad en esófago $(18,2 \%$ al alta, $27,3 \%$ a los 6 meses) y de complicaciones y reintervenciones en todos los cánceres evaluados, especialmente en cáncer de recto (18,4\% de reintervenciones a los 6 meses).

Conclusiones: el estudio de la variabilidad identificada requerirá un adecuado ajuste del riesgo y debería tener en cuenta diferentes factores de estructura. Es necesario mejorar la información recogida en la historia clínica.

Palabras clave: Cáncer digestivo. Cirugía. Variaciones de la práctica médica. Estructura, proceso y resultados de la atención. 


\section{INTRODUCCIÓN}

Uno de los aspectos más debatidos en cirugía oncológica y en otros ámbitos (tanto procedimientos quirúrgicos como médicos) es el de la relación entre el volumen de enfermos intervenidos y los resultados clínicos. Ya hace unos 30 años que se describió la relación entre el incremento en el volumen y la obtención de mejores resultados (1). No obstante, esta relación no se observa siempre $\mathrm{y}$, cuando se produce, se desconoce la razón por la que sucede. Se han planteado diversas hipótesis relacionadas especialmente con factores técnicos de los profesionales (2-6). Sin embargo, si los resultados son mejores en diversos procedimientos o patologías también se debería intentar encontrar factores de organización y coordinación asistencial. Ello puede ser especialmente cierto en el caso de la oncología, cuando es necesario que profesionales de diversas especialidades trabajen conjuntamente en el abordaje diagnóstico y terapéutico: cirugía, oncología, además de los servicios centrales y generales del centro.

La mayor parte de estudios que han analizado la influencia de estos factores del médico/centro, especialmente el volumen, en la variabilidad del proceso y el resultado en cirugía oncológica son retrospectivos (7) y realizados con bases de datos clínico-administrativas (8). Esto explica que el resultado examinado más frecuentemente sea la mortalidad hospitalaria, que carezcan de un ajuste con variables clínicas significativas (como la gravedad y extensión de la enfermedad, las comorbilidades y su tratamiento, o el estado funcional) y que realicen seguimientos a muy corto plazo. Este hecho podría explicar las diferencias observadas con algunos estudios prospectivos con datos primarios (que permiten la inclusión de un mayor número de variables y tienen seguimientos más allá del periodo hospitalario), en los que la relación entre el volumen y los resultados es menos consistente $(8,9)$.

Los estudios tampoco suelen tener en cuenta otros factores de las organizaciones que pueden influir en los resultados, además del volumen, como son las características relacionadas con la estructura y factores relacionados con el proceso siguiendo la aproximación planteada por A. Donabedian para la evaluación de la calidad asistencial $(10,11)$ (Fig. 1).

Con la finalidad de estudiar la variabilidad en el proceso y los resultados de la cirugía oncológica digestiva en Cataluña, así como los factores asociados a estos, siguiendo el paradigma descrito de "estructura, proceso y resultados" e intentando superar las limitaciones anteriores, se planteó un estudio de cohortes multicéntrico. En este manuscrito se describe la metodología seguida y se presentan los principales resultados descriptivos.

\section{MATERIAL Y MÉTODOS}

Estudio observacional con seguimiento retrospectivo y prospectivo de una cohorte de enfermos operados de cán- cer de esófago, estómago, páncreas, recto y metástasis hepáticas. Se invitó a participar a todos los servicios de cirugía general de los hospitales públicos $(\mathrm{n}=51)$ y privados $(\mathrm{n}=10)$ de Catalunya que realizaban este tipo de intervenciones. En la etapa retrospectiva se incluyeron todos los pacientes operados durante el año 2002, en los que se realizó alguno de los procedimientos quirúrgicos descritos en el Anexo (en cualquier de las 4 variables de procedimiento del Conjunto Mínimo Básico de Datos del Alta Hospitalaria-CMBDAH-).

En la etapa prospectiva se incluyeron consecutivamente, durante un periodo de 6 meses, aquellos pacientes operados de los cánceres y procedimientos anteriores (entre noviembre de 2003 y julio de 2005). En ambas etapas se excluyeron aquellos pacientes sometidos a reintervenciones e intervenciones en dos tiempos (con una primera intervención previa al periodo de estudio). Se estimó que la inclusión de 2.500 pacientes con una mortalidad esperada global de aproximadamente el $15 \%$ a los 6 meses de la cirugía (8) permitiría establecer el posible papel pronóstico o predictivo de unas 30 variables independientes en un análisis de regresión logística por pasos, y así construir un modelo de ajuste del riesgo (12) para mortalidad (variable de resultado principal).

En la etapa retrospectiva la principal fuente de información fue la historia clínica. En la prospectiva los datos se obtuvieron en la medida de lo posible directamente del cirujano y, a partir de la historia clínica. Se realizaron evaluaciones en la fase preoperatoria, al alta y a los 3 y 6 meses de esta. Dichas evaluaciones fueron realizadas por profesionales sanitarios (mayoritariamente cirujanos con la especialidad o en formación) específicamente entrenados para ello.

Se diseñaron cuadernos de recogida de datos (CRD), específicos para cada momento de evaluación que se acompañaron de un manual de instrucciones y definiciones operativas para estandarizar la recogida de datos. En el CRD preoperatorio se incluyeron datos administrativos, demográficos, antropométricos y variables relativas al estado basal del paciente: tipo de cáncer, estadificación, pruebas diagnósticas, pruebas complementarias, analítica, antecedentes patológicos y su tratamiento, tratamientos neoadyuvantes (primarios) de radioterapia y quimioterapia, estado funcional -mediante las escalas de Karnofsky Performance Score (13) y Glasgow Coma Scale $(14,15)$ - y riesgo quirúrgico-anestésico -escala ASA (American Society of Anesthesiology) (16)-. En el CRD al alta hospitalaria se recogieron datos de la intervención (profilaxis, localización del tumor, técnica quirúrgica -vía de acceso, resección, linfadenectomía, reconstrucción, anastomosis-, tumor residual, bolsas de hematíes y de plasma y tiempo quirúrgico), las complicaciones intra- y postoperatorias (generales, locales, de la técnica quirúrgica, reintervención y muerte) y datos administrativos. En los CRD de seguimiento a los 3 y 6 meses se obtuvo información sobre las complicaciones, recidivas, reingresos, anatomía patológica, tratamientos adyuvantes (postoperatorios) de radioterapia y quimioterapia, y estado funcional (escala de Karnofsky sólo a los 
6 meses). Se realizaron pruebas piloto en cada fase del estudio para probar los CRD e identificar problemas en los circuitos de comunicación, recogida de datos y tareas de coordinación entre los centros y el equipo investigador.

Se realizó una validación interna de la calidad y consistencia de la información introducida en la base de datos mediante el sistema Cardiff ${ }^{\mathrm{TM}}$ TeleForm $^{\circledR}$.

\section{Análisis}

Se realizó un análisis de la participación. Las principales características demográficas, clínicas, de proceso y resultados de los pacientes incluidos fueron descritas y comparadas por tipo de cáncer y por nivel de complejidad del centro (comarcal, referencia, alta tecnología y privado). Para el estudio de la asociación entre las variables de riesgo, proceso y resultado se aplicó la $\mathrm{Chi}^{2}$, para las variables categóricas y la prueba t de Student o la U de Mann-Whitney (tomando en consideración la distribución de la variable), para las continuas. Así mismo se realizó un análisis de supervivencia tomando el tiempo, desde el ingreso hasta los seis meses de seguimiento o la pérdida de este, o bien, la fecha de fallecimiento del paciente. Los resultados se estratificaron por tipo de cáncer y tomando de forma arbitraria el nivel de significación al 5\%. El manejo de los datos y el análisis estadístico se llevó a cabo utilizando los programas SPSS v.13 y STATA v.9.

La identidad de los participantes (pacientes, cirujanos y centros) se guardó de forma estrictamente confidencial. El protocolo de estudio fue valorado y aprobado por uno de los Comités Éticos de Investigación Clínica de los centros participantes.

\section{RESULTADOS}

\section{Participación}

De los 61 centros que en el año 2002 habían realizado alguna intervención de interés para este estudio, 49 (80\%) aceptaron participar (45 centros públicos y 4 privados). De estos, la gran mayoría (90\%) siguió participando en la fase prospectiva del estudio. En general, los hospitales participantes atendieron al $94 \%$ de pacientes de interés de toda Cataluña y la participación de los hospitales privados fue significativamente menor que la de los públicos (40 versus $88 \%$ ). La figura 2 muestra el diagrama de participación individual según fases.

\section{Características de los pacientes}

Las intervenciones de cáncer de recto fueron las más frecuentes $(55,6 \%)$, seguidas de las de estómago $(26,6 \%)$, metástasis hepáticas $(7,5 \%)$, páncreas $(7,0 \%)$ y esófago $(3,3 \%)$. El volumen de intervenciones por centro según el tipo de cáncer y el nivel de complejidad (Fig. 3) mostró una amplia variabilidad. Se observó una centralización en los cánceres de esófago, páncreas y metástasis hepáticas al ser operados casi exclusivamente en los hospitales de referencia y alta tecnología. Asimismo, se observó una relación de mayor volumen a mayor complejidad del centro principalmente en los cánceres de estómago y recto. En la tabla I se presentan las principales características demográficas y clínicas de los pacientes estudiados. Aunque en general no se observaron diferencias en el perfil de pacientes atendidos según el nivel de complejidad del centro, para el cáncer de recto se constató que a mayor complejidad (en los hospitales públicos), mayor riesgo quirúrgico de los pacientes $(\mathrm{p}<0,001)$.

En el $65,1 \%$ de los casos no se pudo localizar la valoración del estadiaje TNM clínico en la historia clínica. Tampoco se identificó el pT o pN de la anatomía patológica en el 20,6\% de los casos (vivos al alta). Otras variables que también se excluyeron del análisis por presentar un alto porcentaje ( $>20 \%$ ) de valores ausentes (missings) fueron la valoración del estado funcional, la talla, la urea y la clasificación del tumor residual.

\section{Características del proceso asistencial}

Las pruebas diagnósticas aplicadas, así como la utilización de radioterapia y/o quimioterapia neoadyuvante y adyuvante, dependieron principalmente del tipo de cáncer (Tabla II) y se observaron variaciones según la complejidad del centro sólo para algunos de ellos. En el cáncer de recto, la utilización de pruebas diagnósticas fue diferente en los hospitales comarcales (menor práctica de tomografía computerizada y mayor de ecografía abdominal $-\mathrm{p}<0,001-)$ y en los hospitales privados (menor utilización de la colonoscopia, p < 0,001), en comparación con el resto. De forma similar, en el cáncer de estómago los hospitales comarcales realizaron más ecografías abdominales ( $\mathrm{p}<0,001$ ) y los privados menos tomografías computerizadas y esofagogastroscopias $(\mathrm{p}<0,001)$. En el cáncer de recto y en las metástasis hepáticas también se observó variabilidad en los tratamientos primarios donde su aplicación era más frecuente en los centros de mayor complejidad y menor en los hospitales privados $(\mathrm{p}<0,001)$.

En cuanto a la técnica quirúrgica, los centros privados aplicaron mayoritariamente la resección anterior con anastomosis en el cáncer de recto $(73 \%, \mathrm{p}=0,001)$ y las gastrectomías parciales en el cáncer de estómago $(88 \%, \mathrm{p}$ $<0,05)$. Esta última técnica también fue más frecuente a menor complejidad de los hospitales públicos $(p=0,07)$. En el cáncer de esófago, la esofaguectomía toracoabdominal fue más frecuente en los centros de alta tecnología y la cervicoabdominal en los de referencia $(\mathrm{p}<0,001)$. La mediana de la estancia hospitalaria se situó entre 10 y 23 días, siendo menor en los cánceres de estómago, recto y metástasis hepáticas $(\mathrm{p}<0,001)$. 
Tabla I. Características de los pacientes según el tipo de cáncer

\begin{tabular}{|c|c|c|c|c|c|}
\hline & Esófago $(n=99)$ & Estómago $(n=809)$ & Páncreas $(n=214)$ & M. hepáticas $(n=227)$ & Recto $(n=1.689)$ \\
\hline Edad, media (DE) & $63,0(9,7)$ & $68,7(12,5)$ & $64,8(11,4)$ & $63,4(11,3)$ & $68,3(12,0)$ \\
\hline Hombres, n (\%) & $91(92 \%)$ & $504(62 \%)$ & $120(56 \%)$ & $131(58 \%)$ & $1.094(65 \%)$ \\
\hline $\begin{array}{l}\text { Comorbilidades, } \mathrm{n}(\%)^{\mathrm{a}} \\
\text { HTA } \\
\text { EPOC } \\
\text { Diabetes mellitus } \\
\text { ICC } \\
\text { Enfermedad isquémica } \\
\text { AVC u otros CV }\end{array}$ & $\begin{array}{c}25(25 \%) \\
29(29 \%) \\
10(10 \%) \\
6(6 \%) \\
9(9 \%) \\
4(4 \%)\end{array}$ & $\begin{array}{c}285(36 \%) \\
149(18 \%) \\
128(16 \%) \\
77(10 \%) \\
102(13 \%) \\
60(8 \%)\end{array}$ & $\begin{array}{l}80(38 \%) \\
20(9 \%) \\
49(23 \%) \\
22(10 \%) \\
14(7 \%) \\
10(5 \%)\end{array}$ & $\begin{array}{c}60(28 \%) \\
24(11 \%) \\
26(12 \%) \\
12(6 \%) \\
13(6 \%) \\
12(6 \%)\end{array}$ & $\begin{array}{l}694(42 \%) \\
314(19 \%) \\
291(18 \%) \\
206(13 \%) \\
197(12 \%) \\
136(8 \%)\end{array}$ \\
\hline $\begin{array}{l}\text { № comorbilidades tratadas, } \\
\text { Ninguna } \\
1 \text { ó } 2 \\
3 \text { o más }\end{array}$ & $\begin{array}{c}53(54 \%) \\
38(38 \%) \\
8(8 \%)\end{array}$ & $\begin{array}{l}342(42 \%) \\
349(43 \%) \\
118(15 \%)\end{array}$ & $\begin{array}{l}104(49 \%) \\
82(38 \%) \\
28(13 \%)\end{array}$ & $\begin{array}{c}119(52 \%) \\
88(39 \%) \\
20(9 \%)\end{array}$ & $\begin{array}{l}701(42 \%) \\
697(41 \%) \\
291(17 \%)\end{array}$ \\
\hline $\begin{array}{l}\text { Escala ASA, n (\%)c } \\
\text { I-II } \\
\text { III } \\
\text { IV-V }\end{array}$ & $\begin{array}{c}38(38 \%) \\
53(54 \%) \\
4(4 \%)\end{array}$ & $\begin{array}{c}428(53 \%) \\
286(35 \%) \\
43(5 \%)\end{array}$ & $\begin{array}{c}117(55 \%) \\
80(37 \%) \\
4(2 \%)\end{array}$ & $\begin{array}{c}99(44 \%) \\
106(47 \%) \\
8(4 \%)\end{array}$ & $\begin{array}{l}951(56 \%) \\
565(33 \%) \\
80(5 \%)\end{array}$ \\
\hline $\begin{array}{l}\text { Estadiaje } \mathrm{pT}, \mathrm{n}(\%)^{\mathrm{c}} \\
\text { No determinado }\left(\mathrm{pT}_{\mathrm{x}}\right) \\
\mathrm{pT}_{0} \\
\text { Volumen pequeño } \\
\left(\mathrm{pT}_{1} \circ \mathrm{pT}_{2}\right) \\
\text { Volumen grande } \\
\left(\mathrm{pT}_{3} \circ \mathrm{pT}_{4}\right)\end{array}$ & $\begin{array}{c}1(1 \%) \\
0(0 \%) \\
29(29 \%) \\
47(48 \%)\end{array}$ & $\begin{array}{c}16(2 \%) \\
11(1 \%) \\
289(36 \%) \\
338(42 \%)\end{array}$ & $\begin{array}{c}8(4 \%) \\
2(1 \%) \\
55(26 \%) \\
94(44 \%)\end{array}$ & - & $\begin{array}{c}28(2 \%) \\
43(3 \%) \\
416(25 \%) \\
975(58 \%)\end{array}$ \\
\hline $\begin{array}{l}\text { Estadiaje } \mathrm{pN}, \mathrm{n}(\%)^{\mathrm{c}} \\
\text { No determinado }\left(\mathrm{pN}_{\mathrm{x}}\right) \\
\mathrm{pN}_{0} \\
\text { No regional }\left(\mathrm{pN}_{1}\right) \\
\text { Regional }\left(\mathrm{pN}_{2} \circ \mathrm{pN}_{3}\right)\end{array}$ & $\begin{array}{c}4(4 \%) \\
31(31 \%) \\
28(28 \%) \\
16(16 \%)\end{array}$ & $\begin{array}{c}34(4 \%) \\
231(29 \%) \\
192(24 \%) \\
194(24 \%)\end{array}$ & $\begin{array}{c}23(11 \%) \\
63(29 \%) \\
70(33 \%) \\
2(1 \%)\end{array}$ & - & $\begin{array}{c}64(4 \%) \\
808(48 \%) \\
333(20 \%) \\
227(13 \%)\end{array}$ \\
\hline
\end{tabular}

M. hepáticas: metástasis hepáticas; DE: desviación estándar; HTA: hipertensión arterial; EPOC: enfermedad pulmonar obstructiva crónica; ICC: insuficiencia cardiaca congestiva; AVC: accidente vascular cerebral; CV: cerebrovasculares; ASA: American Society of Anesthesiology: pT: extensión del tumor; pN: extensión de la diseminación a los ganglios linfáticos.

'Variable multirrespuesta, el porcentaje representa el \% de pacientes con al menos esa comorbilidad; 'bEnfermedad isquémica cardiaca; 'Porcentaje calculado sobre el total, la suma hasta llegar a $100 \%$ representa el porcentaje de casos perdidos.

\section{Resultados de la atención}

Las complicaciones sistémicas o generales fueron las más frecuentes durante la hospitalización ya que se presentaron en más del $40 \%$ de los casos (especialmente las renales $-16,5 \%-$, excepto en el cáncer de esófago, en el que las más frecuentes fueron las pulmonares $-45,5 \%-$ ). Las complicaciones hasta el alta, debidas a la técnica quirúrgica y las de la herida quirúrgica (locales), se produjeron en el 24,0 y $18,1 \%$ de los pacientes respectivamente (Fig. 4A). Se observaron diferencias según el nivel de complejidad del hospital, siendo menor el \% de complicaciones generales $(p<0,0001)$ y de la herida $(p=0,001)$ observadas en los centros de alta tecnología (en los hospitales privados sólo en el caso de las complicaciones generales), respecto del resto.

La presentación de recidivas, a los $3(5,6 \%)$ y 6 meses $(11,2 \%)$ del alta, varió en función del cáncer (Fig. 4B). La frecuencia de reintervenciones, hasta el alta $(9,9 \%)$ y hasta los 6 meses $(17,8 \%)$, también cambió en función del cáncer (Fig. 4C). Las reintervenciones en cáncer de recto fueron más frecuentes a mayor complejidad y máxime en los hospitales privados, tanto a los 3 como a los 6 meses $(20,7$ y $30,2 \%$, respectivamente $-p<0,01-)$.

La mortalidad quirúrgica intrahospitalaria bruta (sin ajustar) osciló entre el 2,6\% en las metástasis hepáticas y el 18,2\% en el cáncer de esófago, doblándose aproximadamente para casi todos los tipos de cáncer a los 6 meses (Fig. 4D). Sólo en el caso del cáncer de estómago el nivel de complejidad del centro se mostró asociado a la mortalidad a los 6 meses después de ajustar por edad y ASA del paciente $(\mathrm{p}<0,01)$, siendo los hospitales de alta tecnología los que presentaron mejores resultados.

\section{DISCUSIÓN}

Este estudio ha intentado describir el perfil de pacientes operados de cáncer digestivo, su proceso asistencial y resultados a corto-medio plazo, en gran parte de los hos- 
Tabla II. Características del proceso asistencial según el tipo de cáncer

\begin{tabular}{|c|c|c|c|c|c|}
\hline & Esófago ( $n=99)$ & Estómago $(n=809)$ & Páncreas $(n=214)$ & M. hepáticas ( $n=227)$ & $\operatorname{Recto}(n=1.689)$ \\
\hline $\begin{array}{l}\text { Circunstancia de ingreso, } \mathrm{n}(\%) \\
\text { Programado } \\
\text { Urgente }\end{array}$ & $\begin{array}{l}86(87 \%) \\
13(13 \%)\end{array}$ & $\begin{array}{l}647(80 \%) \\
162(20 \%)\end{array}$ & $\begin{array}{c}136(64 \%) \\
78(36 \%)\end{array}$ & $\begin{array}{c}218(96 \%) \\
9(4 \%)\end{array}$ & $\begin{array}{c}1.461(87 \%) \\
224(13 \%)\end{array}$ \\
\hline $\begin{array}{l}\text { № de pruebas diagnósticas, n (\%) } \\
1 \\
2 \\
3 \text { o más }\end{array}$ & $\begin{array}{c}0(0 \%) \\
14(14 \%) \\
85(86 \%)\end{array}$ & $\begin{array}{c}4(1 \%) \\
437(54 \%) \\
368(45 \%)\end{array}$ & $\begin{array}{c}2(1 \%) \\
103(48 \%) \\
109(51 \%)\end{array}$ & $\begin{array}{c}4(2 \%) \\
152(67 \%) \\
71(31 \%)\end{array}$ & $\begin{array}{c}33(2 \%) \\
712(42 \%) \\
944(56 \%)\end{array}$ \\
\hline Tomografía computada, n (\%) & $99(100 \%)$ & $663(82 \%)$ & $201(94 \%)$ & $208(92 \%)$ & $1.267(75 \%)$ \\
\hline Esofagogastroscopia, n (\%) & $97(98 \%)$ & $774(96 \%)$ & - & - & - \\
\hline Tránsito esofagogastroduodenal, n (\%) & $57(58 \%)$ & - & - & - & - \\
\hline Ecografía abdominal, n (\%) & - & $246(30 \%)$ & $147(69 \%)$ & $69(30 \%)$ & $614(36 \%)$ \\
\hline Resonancia magnética, n (\%) & - & - & $77(36 \%)$ & $72(32 \%)$ & - \\
\hline Colonoscopia, n (\%) & - & - & - & - & $1534(91 \%)$ \\
\hline Radioterapia neoadyuvante ${ }^{\mathrm{a}}$, n (\%) & $15(16 \%)$ & $1(0 \%)$ & $1(1 \%)$ & $6(3 \%)$ & $307(18 \%)$ \\
\hline Quimioterapia neoadyuvantea, n (\%) & $20(20 \%)$ & $13(2 \%)$ & $2(1 \%)$ & $45(20 \%)$ & $283(17 \%)$ \\
\hline $\begin{array}{l}\text { Técnica quirúrgicabacc } n \text { (\%) } \\
\text { Técnica A } \\
\text { Técnica B } \\
\text { Técnica C } \\
\text { Cirugía paliativa } \\
\end{array}$ & $\begin{array}{l}25(25 \%) \\
39(39 \%) \\
13(13 \%) \\
7(7 \%) \\
\end{array}$ & $\begin{array}{c}248(31 \%) \\
445(55 \%) \\
- \\
73(9 \%) \\
\end{array}$ & $\begin{array}{c}142(66 \%) \\
13(6 \%) \\
15(7 \%) \\
37(17 \%) \\
\end{array}$ & $\begin{array}{c}80(35 \%) \\
62(27 \%) \\
25(11 \%) \\
14(6 \%) \\
\end{array}$ & $\begin{array}{l}256(15 \%) \\
180(11 \%) \\
813(48 \%) \\
151(9 \%) \\
\end{array}$ \\
\hline Bolsas de hematíes $(\geq 1), \mathrm{n}(\%)$ & $33(33 \%)$ & $264(33 \%)$ & $101(47 \%)$ & $59(26 \%)$ & $364(22 \%)$ \\
\hline Tiempo (h) quirúrgico, mediana (RIC) & $4,6(1,7)$ & $3,0(1,3)$ & $4,7(1,8)$ & $3,8(1,5)$ & $2,8(2,5)$ \\
\hline Radioterapia adyuvante ${ }^{a}$, n (\%) & $29(17 \%)$ & $259(16 \%)$ & $93(37 \%)$ & $134(21 \%)$ & $823(29 \%)$ \\
\hline Quimioterapia adyuvante ${ }^{a}$, n (\%) & $26(26 \%)$ & $255(32 \%)$ & $90(42 \%)$ & $134(59 \%)$ & $780(46 \%)$ \\
\hline Estancia (días), mediana (RIC) & $20(22)$ & $16(17)$ & $23(19)$ & $10(6)$ & $13(11)$ \\
\hline
\end{tabular}

M. hepáticas: metástasis hepáticas; RIC: rango intercuartílico.

aPorcentaje calculado sobre el total; ' ${ }^{2}$ En un $12,8 \%$ de casos la técnica no estaba disponible (esófago 15\%, estómago $5 \%$, páncreas $7 \%$, metástasis hepáticas $20 \%$, recto $17 \%)$; Para cáncer de esófago: técnica $A=$ esofaguectomía toracoabdominal, técnica $B=$ esofaguectomía cervicoabdominal, técnica $C=$ esofaguectomía cervicotoracoabdominal; para cáncer de estómago, técnica $\mathrm{A}$ = gastrectomía total, técnica B = gastrectomía parcial; para cáncer de páncreas: técnica $\mathrm{A}=$ duodenopancreatectomía cefálica, técnica $B=$ pancreatectomía corporo/caudal, técnica $C=$ duodenopancreatectomía total; para $m$. hepáticas: técnica $A=$ segmentectomía, técnica $B=$ hepatectomía, técnica $C$ = otras hepatectomías; para cáncer de recto: técnica $A=$ resección abdominoperineal (Miles), técnica $B=$ resección anterior (Hartmann), técnica $C=$ resección anterior con anastomosis.

pitales que realizan este tipo de cirugía en Cataluña. Sólo se incluyeron aquellos procesos con un importante impacto sobre la calidad de vida y considerados de terciarismo (de alta complejidad técnica y con elevados requerimientos de recursos estructurales, o de calificación de los profesionales). En general, no se observaron diferencias en las características de los pacientes operados, según el nivel de complejidad del centro, pero no se pudo analizar el estadiaje clínico-patológico y otras variables de estado funcional por presentar un elevado porcentaje de valores ausentes. Las características del proceso asistencial y los resultados fueron, a grandes rasgos, los esperados, excepto la elevada mortalidad al alta y hasta los 6 meses de seguimiento en el cáncer de esófago, así como la frecuencia de complicaciones y reintervenciones en las diversas cirugías evaluadas. Estos resultados contrastan con algunos publicados -tanto en España como en otros países desarrollados (8,17-29)-, y pueden explicarse, sólo en parte, por la inclusión de intervenciones de carácter paliativo y urgentes (también por el cierre de la colostomía en los pacientes intervenidos con la técnica de Hartmann en el cáncer de recto), aunque también debe tenerse en cuenta las diferencias en las características de las series incluidas (30). La elevada presentación de recidivas hasta los 6 meses de seguimiento se dio especialmente en los casos de cirugía paliativa no pudiendo descartarse que se tratara realmente de progresiones. No obstante, algunos de estos resultados no llegan a estándares propuestos en nuestro contexto (31).

La variabilidad identificada en algunos aspectos de proceso no se tradujo en diferentes resultados según la complejidad del hospital, excepto en el cáncer de recto, para las reintervenciones, y en el cáncer de estómago, para la mortalidad. Pero no se han identificado claros patrones o estilos de práctica durante el proceso asistencial que puedan explicarlo. En ambos cánceres la realización de pruebas diagnósticas mostró un patrón similar, con una tendencia a realizar un menor número de pruebas en 
los hospitales privados y a utilizar pruebas menos complejas (ecografías abdominales) en los hospitales comarcales. También se observó un comportamiento similar en estos cánceres, entre la radicalidad de la técnica quirúrgica y la complejidad del centro: menos gastrectomías totales y menos resecciones con colostomía en los centros privados, en comparación con los públicos y, dentro de estos, en los de menor complejidad (sólo para el cáncer de estómago).

Además, aunque no se muestran los datos, en el cáncer de recto a medida que aumentaba el número de intervenciones por centro, la variabilidad en el porcentaje de cirugía conservadora de esfínteres ( nor, como era de esperar, y tendiendo hacia el $70 \%$ de los casos (excepto en un centro) $(17,21-23)$. Sin embargo, este patrón no se observó para el cáncer de estómago, donde la variabilidad en la radicalidad era importante para cualquier volumen de intervenciones, incluso en los centros de mayor volumen (desde el 25 al 68\% de gastrectomías totales). En los otros cánceres de menor frecuencia, a pesar de existir cierta variabilidad en el proceso y los resultados según el nivel de complejidad del centro, no se detectaron diferencias estadísticamente significativas, probablemente por la escasa potencia estadística de los análisis.

No obstante, existió una elevada variabilidad en el volumen de intervenciones realizadas en cada centro, en todos los cánceres, especialmente en los hospitales de referencia. Dado que no siempre un elevado volumen de intervenciones garantiza unos buenos resultados $(8,32) \mathrm{y}$ que pueden existir otros factores de proceso y estructura determinantes, parece que lo más razonable antes de recomendar cualquier cambio de la atención sanitaria sería el desarrollo de modelos de ajuste del riesgo que recojan adecuadamente la gravedad del paciente (33) y que tengan en cuenta diferentes factores de estructura, para el estudio de las variaciones en el proceso y resultados encontradas. Este estudio permitirá la definición de estos modelos pero se anticipan una serie de limitaciones a tener en cuenta.

En primer lugar, la falta de estandarización y ausencia de información relevante (estadiaje, estado funcional, al- gunos aspectos de la técnica quirúrgica) en la historia clínica, principal fuente de información. Todo ello conlleva una menor capacidad para poder ajustar adecuadamente la gravedad o riesgo de los pacientes y el proceso asistencial pero pone de relieve la importancia de obtener e incluir en la historia clínica (o en otros instrumentos/sistemas de información) estos datos para poder evaluar la efectividad de la práctica clínica.

Además, lo anterior junto a la posible variabilidad en este proceso por la colaboración de diversos profesionales (prácticamente una persona diferente en cada centro), pueden haber menguado la validez y fiabilidad de la información. Pero al comparar las variables comunes, entre nuestro estudio y el CMBDAH, se comprobó que no había diferencias (datos no mostrados).

Finalmente, el seguimiento de los resultados se limitó a los 6 meses después de la cirugía. En alguno de los cánceres estudiados puede tratarse de un periodo bastante corto para su evaluación, pero significa un avance importante en relación a la mayoría de estudios que limitan sus análisis al periodo intrahospitalario, especialmente los basados en el CMBDAH.

\section{AGRADECIMIENTOS}

Este estudio ha sido financiado parcialmente por el Instituto de Salud Carlos III, a través del Programa de Promoción de la Investigación Biomédica y en Ciencias de la Salud de ayudas para proyectos de investigación $(03 / 1641)$ y para la realización de estudios de investigaciones sobre evaluación de tecnologías sanitarias (05/90185). Se agradece también a la Red de investigación cooperativa de cáncer (RD06/0020/0089).

La Generalitat de Catalunya ha reconocido a la Agència d'Avaluació de Tecnologia i Recerca Mèdiques como grupo de investigación en Avaluació de serveis i Resultats en salut (2009SGR 1317).

Los autores quieren agradecer a Júlia López y Mercè Salvat su colaboración durante el trabajo de campo del estudio, y a todos los profesionales su participación en la recogida de datos de los hospitales participantes. 
Anexo. Tipo de cáncer y procedimientos quirúrgicos seleccionados según los códigos de la CIE-9 en el CMBDAH

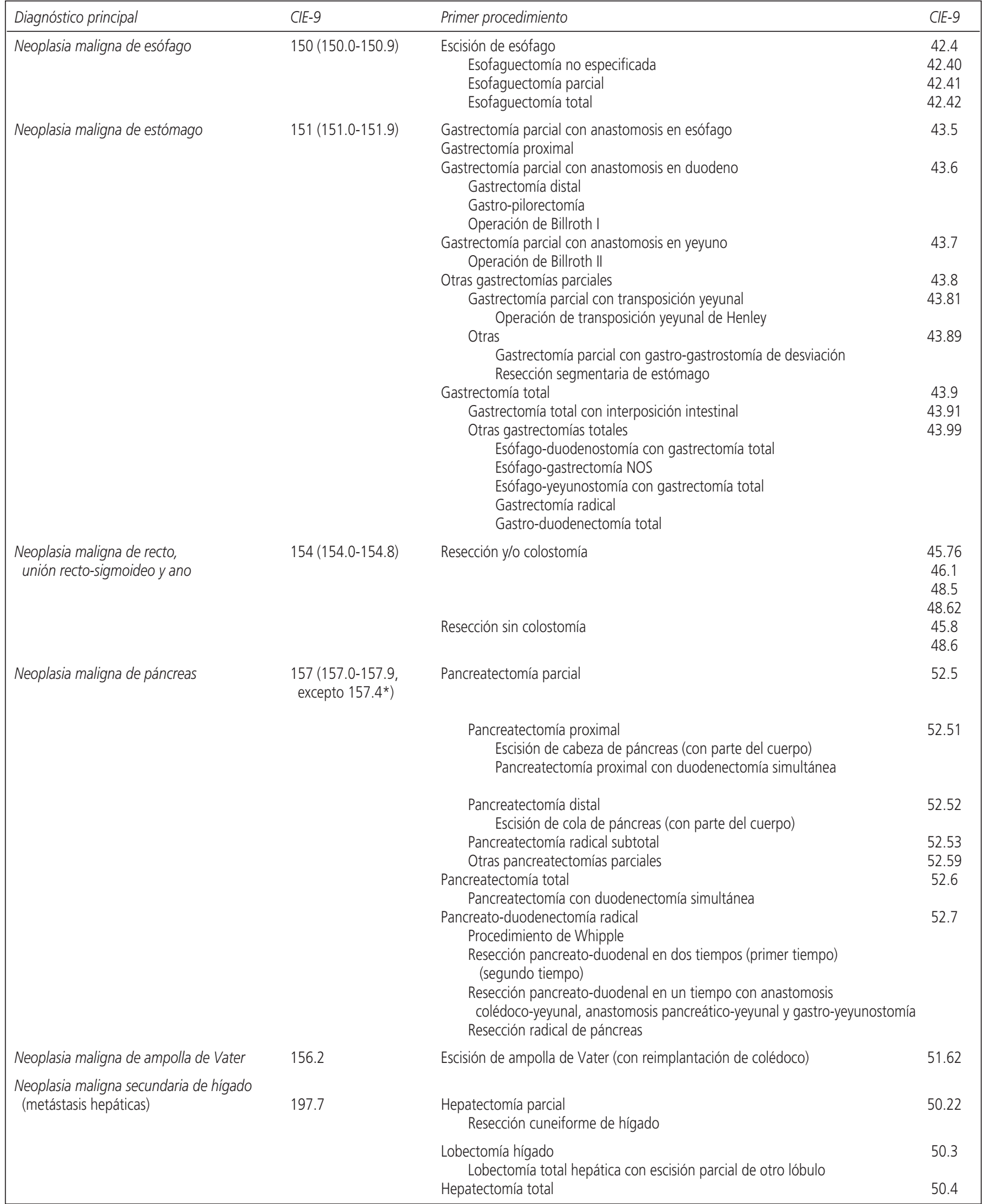

*Islotes de Langerhans; CIE-9: Clasificación Internacional de Enfermedades 9a revisión; CMBDAH: Conjunto Mínimo Básico de Datos del Alta Hospitalaria. 